\title{
Kombinace antegrádní a retrográdní rekanalizace chronicky uzavřené věnčité tepny
}

Ačkoliv se o výhodnosti

a dlouhodobém účinku rekanalizací chronicky uzavřených věnčitých tepen vedou stále diskuse, ${ }^{(1)}$ technika těchto výkonů v posledních letech výrazně pokročila. Tepny lze rekanalizovat již nejen antegrádním přístupem $\mathrm{z}$ aorty, ale rovněž retrográdně cestou kolaterály $z$ druhé věnčité tepny. ${ }^{(2)}$ 42letý muž s řadou rizikových faktorů

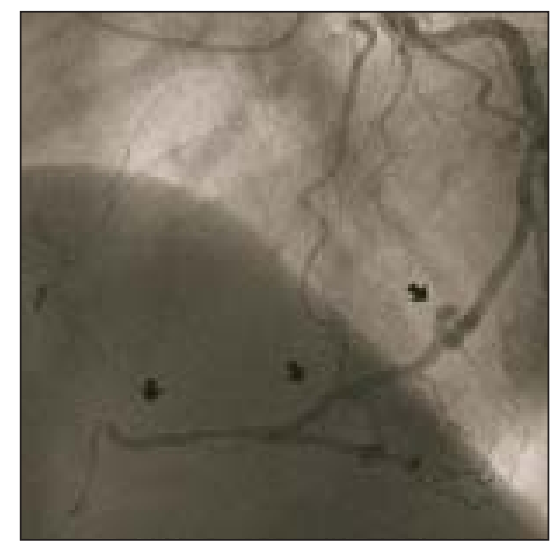

Obr. 1 Koronarogram levé věnčité tepny v levé šikmé projekci; silná kolaterála perfunduje periferii ACD (šipky)

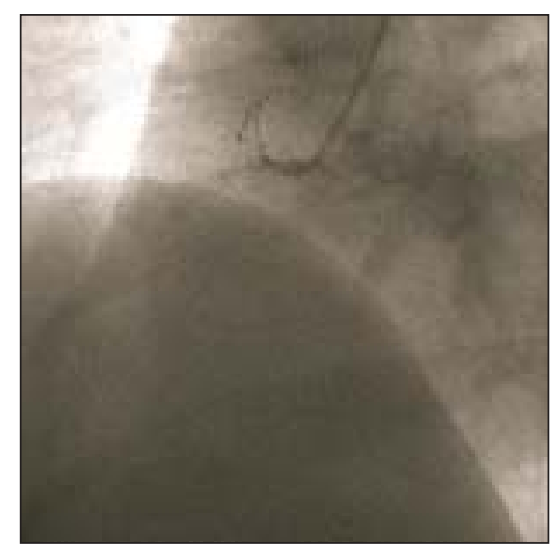

Obr. 2 Koronarogram ACD s uzávěrem $\mathrm{v}$ jejím odstupu aterosklerózy a s pět let známým chronickým uzávěrem pravé věnčité tepny (ACD) byl přijat pro klidové stenokardie s mírně nadhraniční hodnotou troponinu I. Při selektivní koronarografii byla nalezena další progrese uzávěru ACD ve srovnání s minulým vyšetřením.

Současná délka uzávěru činila nyní $8 \mathrm{~cm}$ (obrázky 1 a 2). Ostatní nález na věnčitých tepnách se za posledních pět let nezměnil. Cestou levé věnčité tepny (ACS) byl přes kolaterálu spojující ramus circumflexus a ACD zaveden retrográdně vodič do uzávěru, který byl etážově dilatován balonkovým katetrem $\mathrm{v}$ délce $7 \mathrm{~cm}$, až téměr $\mathrm{k}$ odstupu $\mathrm{ACD} \mathrm{z}$ aorty. Antegrádně byl přes uzávěr zaveden vodič do lumen, vytvořeném retrográdní rekanalizací (obrázek 3)

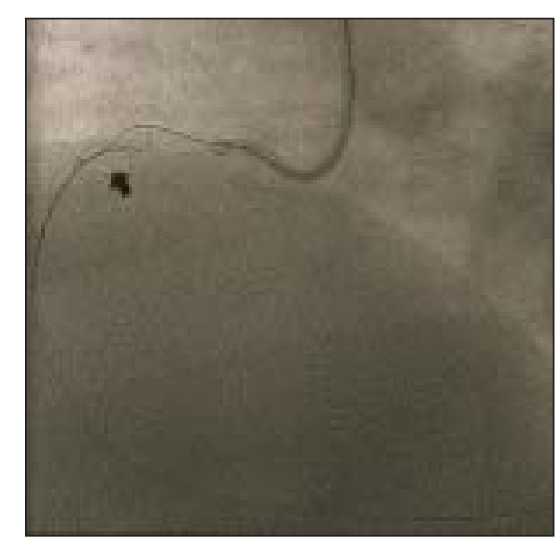

Obr. 3 Spojení retrográdně a prográdně zavedeného vodiče („kissing wires“) (šipka)

a po tomto vodiči byly do uzávěru postupně zavedeny balonkové katetry, kterými byl celý uzávěr postupně dilatován. Do ACD v rozsahu celého původního uzávěru byly posléze implantovány tři stenty vylučující léky (lékové stenty) v celkové délce

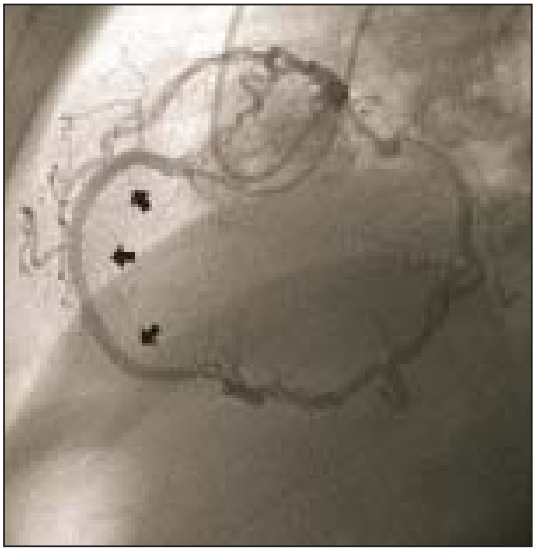

Obr. 4 Současný nástř̌ik do obou věnčitých tepen na závěr výkonu; ACD s implantovanými stenty označena šipkami

92 mm (obrázek 4). Po výkonu se pacient zbavil obtíží.

Technika kombinované antegrádní a retrográdní rekanalizace byla recentně popsána japonskými autory a nazvána CART (Controlled Antegrade and Retrograde subintimal Tracking). ${ }^{(2)}$ Ačkoliv nejsou zatím známy dlouhodobé výsledky těchto intervencí zdá se velmi pravděpodobné, že v podobných ojedinělých případech může tento způsob léčby nahradit chirurgickou revaskularizaci.

\section{LITERATURA}

1. Staněk V. Máme se snažit o pozdní otevření infarktové tepny? Konec jedné hypotézy. Cor Vasa 2007;49:43-4.

2. Surmely JF, Tsuchikane E, Katoh O, et al. New concept for CTO recanalization using controlled antegrade and retrograde subintimal tracking: the CART technique. J Invasive Cardiol 2006;18:339-40.

\section{Josef Veselka, Radka Duchoňová, David Zemánek}

Kardiologické oddělení, Kardiovaskulární centrum dospělých, Fakultní nemocnice v Motole, Praha, Česká republika

Adresa: doc. MUDr. Josef Veselka, CSc., FESC, FSCAI, Kardiologické oddělení, Kardiovaskulární centrum dospělých, FN Motol, V úvalu 84, 15006 Praha 5, Česká republika, e-mail: veselka.josef@seznam.cz 